\title{
Transfer from the Church to the Street Discussion on the Secularization of European Medieval Religious Dramas
}

\author{
Shuping Wang ${ }^{1, *}$ \\ ${ }^{1}$ Fuzhou University of International Studies and Trade, Fuzhou, Fujian 350202, China \\ *Corresponding author. Email: 1195791174@qq.com
}

\begin{abstract}
In the Middle Ages of Europe, a new kind of drama, the religious drama, was developed. It evolved from the Redundancy of Words of church worship, and then evolved into mystery, miracle and moral drama. In the late Middle Ages, secular factors continued to permeate the performances of religious dramas, promoting its secularization in five aspects: performance venues, theatrical themes and content, the form of performance, the increase of harlequins, the secularization of church music and the birth of urban drama, ultimately leading to the arrival of the Shakespeare literati era.
\end{abstract}

Keywords: religious dramas, Redundancy of Words, secularization, urban drama

\section{INTRODUCTION}

Religion and drama have always been closely linked. The ancient Greek tragedy was born from the sacrificial offering of Dionysian gods. Wang Guowei also believed that the source of Chinese opera was witchcraft performances. Theatrical performances have the function of "entertaining God" to communicate people and deities, a way for people to express their devotion to gods. "For people before the Renaissance, drama has not lost its connection with religious rituals, it has to do with the change of the seasons of growth and death, and it has to do with the universal need for worship, celebration and rejuvenation. Therefore, at this time, the whole group (both performers and spectators) is involved. "1

However, starting from the 4 th century $\mathrm{AD}$, as Christianity developed and expanded in continental Europe, theatrical performances were repeatedly banned and destroyed by the church due to its distinctive entertainment, and Roman comedies were expelled from the church for its "devious playfulness and comic parody". The tragedy and comedy traditions of ancient Greece and ancient Rome were severed, and the history of European theater entered a blank period of about six centuries. Paradoxically, in the 10th century, with its tenacious vitality, a new breed was born in a well-regulated church. This is the medieval church ritual drama.

William Tydeman. The Theatre in the Middle Ages[M]. Beijing: Cambridge, 1978.

\section{THE BIRTH OF RITUAL WORSHIP DRAMA}

Although the Holy See chased the drama, the drama activities in the folk celebrations were still lively. The church was helpless about the phenomenon of "forbidden and endless" drama, and then changed its mindset to support the theater to serve the teaching of doctrine. Theatrical performances are held in various festivals.

Medieval religious dramas were born from the Christian Mass and the Eucharist rituals. The Eucharist rituals are often considered to have a strong theatrical color. "When Mass was recited with a solemn ritual, it immediately became the simplest and noblest drama." 2 And the opening speech, the epilogue, or the closing phrase added in the mass ceremony, that is, "Derivatives", laid the foundation for the birth of religious drama. "Anthem" or "sutra" is the earliest form of "Derivatives". "Derivatives" was originally a group of priests taking turns singing duet after singing, but later developed into a "liturgical drama" with action and dialogue. The earliest and more complete literature on religious drama in medieval Europe is a version of the 10th-century St. Martin Abbey's "Visit the Holy Sepulchre". This drama belongs to the Easter drama in religious drama. The play mainly introduces three women named Maria who came to Jesus 'grave and were inspired by the angels about Jesus' resurrection:

Angel: Followers of Jesus, who are you looking for in the Holy Sepulchre?

Yang Huilin. Christianity Background and Cultura Extension [M]. Harbin: Heilongjiang People's Publishing House, 2002, p. 214 
Three women: Angels, we are looking for the crucifixion Jesus, the Jesus of Nazareth.

Angel: He is not here. As the prophecy says, he has risen to heaven. Go and declare to the people: Jesus has ascended into heaven from the holy tomb.

The angel and the three shepherds are played by male priests. The dialogue takes place in the form of hymns, usually performed in churches. Later, the church had specific requirements for "Derivatives" performances. "Derivatives" in this ritual led to the birth of religious drama. In the 10th century, this "derivation" became increasingly complex, with dramatic factors such as plots, costumes, and scenery being strengthened. For example, three Marys were added to sell spices in small shops, and you met Mehan and Peter. The resurrection appears. This "ritual play" has continued to grow and prosper during Christian Mass, such as Easter, Christmas, Good Friday, and so on.

In addition to "In Search of the Holy Sepulchre", there is also a famous Easter drama "Travel". "Travel" begins with the resurrection of Jesus and catches up with the two disciples on their way out, but is not recognized. A narration performed by a choir or a choir describes their arrival in a village at night. The disciples convinced Jesus not to hurry and go with them to rest. What followed was a pantomime where Jesus sat at the table, sharing bread with the two disciples, and suddenly disappeared. The disciples were astounded and regretted for their laziness and for not recognizing Jesus who appeared to themselves. At this time Jesus appeared again, and the disciples sang a revolving song in praise of the resurrection, and the performance ended in prayer. The significance of this play is that its plot does not fully comply with the Bible, and the lines have polished the words of the Bible, helping the religious drama shift from ritual to drama.

Religious drama entered a period of all-round development in the second stage of medieval civilization (1050-1300). The rise of the church helped the development of the entire ritual play. After the church was built, the religious drama was changed from the monastery to the church. The spacious main hall becomes a place for performing and watching.

\section{THE SECULARIZATION OF RELIGIOUS DRAMA}

Church ritual dramas have continued to develop, and plots, content, and performance methods have also been enriched. Churches with limited space cannot accommodate the scale of theater performances, and the vulgar content of ceremonial dramas has caused the theater to move from the church to the outer square. After the 12th century, religious dramas no longer took the church as the background, but performed on squares and streets. Therefore, a new type of theater religious drama matured, and the mystery drama was born first.

Medieval religious plays were divided into several types, early Mystery Plays, mid-term Miracle Plays, and late Morality Plays. Mystery plays can be subdivided into Plays of the Easter Season, The Passion Plays, Nativity Plays and other forms. The mystery drama is based on the Bible and shows the birth, suffering, and resurrection of Christ. The miracle tells the miracles of the Virgin Mary and the saints. Most of them are related to Mary. The plots are similar. The structure is sinners who sin. They sell their souls to the devil. Moral drama is relatively late, it is a more realistic and secular drama. It takes human good and evil as the theme and promotes Christian ethics by anthropomorphizing various qualities such as good, evil, friendship, and honesty.

\section{A. Transfer of performance venues - from the church to the street}

Once the drama was removed from the church, its interaction with the citizens strengthened, and the religious drama moved outside the church to perform, gradually forming a dual control of the church and nonreligious groups. "3 The church contributed its praise and encouragement, while secular groups contributed money and manpower. The form of open-air performances gave more secular audiences the opportunity to feedback secular acceptance habits and standards of appreciation to religious dramas. Various chambers of commerce and guilds at the time Nonreligious organizations, such as the Fan Club, have also participated in the sponsorship and performance of theatrical performances. They are responsible for a repertoire in the serials, such as the wood union is responsible for the "Noah" drama; the hospital is responsible for the "Jesus Redemption" drama and so on. This series is performed on a mobile double-floor float. The upper part of the float is the performance stage, and the lower part is the place where the actors make up and change clothes. Each car plays its own plot at the same time, so that the masses can start from scratch. We watch the whole show in the end. This series can be performed for several days. For example, in 1498, the street crucifixion in Frankfurt was performed for 4 days. Another drama about saints lasted 61908 lines, and it is said that in 1536 Performed for 40 days. In addition to this float-like performance, there is also a fixed surround theater, similar to the Roman amphitheater. The picture of The Martyrdom St. Apollonia shows us the form of performance at that time.

(United States) Brockett (O.G.). History of World Drama [M]. Translated by Hu Yaoheng. Beijing: China Drama Press, 1987, p. 115 . 
The religious drama gradually formed a scale, and the participants gradually expanded from the pastor to the local officials, lawyers, and the people and businessmen in the city. There are grand performances at religious festivals, the reign of the King, or disaster relief. The stage also extends from the church to the outside of the church, from a fixed location to a mobile performance, from the construction of a temporary viewing tent to the construction of a theater.

In the 14th and 15th centuries, in addition to street theater, city halls around Europe and the auditoriums of universities or other types of schools also became venues for theater performances. The so-called "serial drama" is often performed for a few days or dozens of days. The serials of the city parade later pursued onesided pursuit of secondary roles and low-level tastes in external form, and even used physiological and pathological defects to make jokes. As the negative character in the play, the devil is ugly and seductive, which can not only promote the progress of the plot, but also relax the tension of the audience.

\section{$B$. Changes in the theme and content of the performance - from the Bible to the life in the city}

The later the Middle Ages, the more the subject matter of religious dramas escaped the content of the Bible, not only adding to the folk legends and legends of the saints, such as the miracle drama "Saint Nicholas", more from folklore, but It has added a lot of the content of life in the city. Through detailed descriptions, it has continuously enriched the plot of religious dramas, especially the later moral dramas. It has become more distinct. Its appeal to the masses is more and more manifested in those that reflect the customs of the world Plot and content. For example, "Second Shepherd's Play" is a representative work of British religious drama. It is based on chapters 2 to 8 of "Gospel of Luke". The basic plot is about Christmas Eve. In front of the shepherds, he proclaimed the birth of Jesus Christ and led them to the manger in Bethlehem's inn to worship the infant Jesus. There are 754 lines in the whole play, of which 628 lines are about the conflict between the shepherd and the horse thief Mike. The sheep stealer Mike cheated the trust of three poor shepherds and stole a sheep in the middle of the night. When the shepherd found his house, Mike's wife pretended to have just given birth and put the lamb in the cradle. It was covered by a white cloth. The shepherd had just cleared his doubts and wanted to leave. Suddenly he hadn't given the child a gift. When he opened the cloth, he found a sheep's nose. At first, they heard Mike said that the child was disabled. It was quite funny and stupid. This first half of the description uses the living conditions of the three shepherds to expose the brutal exploitation of slaves by medieval churches and nobles, and their conflict with Mike is more similar to Greco-Roman comics, both propaganda of religious doctrines and Meet the public's interest in watching drama. "Secularization includes two completely different aspects at the same time. One is that the theological thinkers are trying to use secular theory to completely change the stale rhetoric and stereotypes that have been popular for a long time, and to rebuild the spiritual system of the Christian faith; the other is people's secular taste and The world winds are coming to an instant, so the entertainment, comedy and irony in urban literature has become an irresistible trend. "4

In addition, we see the play of the Virgin Mary, which is also full of worldly interest. Originally, Mary was only the mother of Christ in the Bible, and she was conceived by the Holy Spirit as a virgin. She did not write more about her, but the Catholic Church deified Mary first. In the miracle drama, Maria has the power to save the world. Magical power, and then in topics such as "Mary's Marriage" and "Assumption of the Virgin", Maria was secularized and became an ordinary woman. When she was about to die, she asked her disciples to take care of her body. Because it is said that the whole body is the residence of the soul after the resurrection, and she repeatedly said in her last words that she should not "see the face of the devil", which is exactly the same as that of an ordinary old man before his death. And Mary's husband, Joseph, also behaved like a market man.

In addition, the change of this theme is also reflected in the design of some plots, such as the theft plot and deception. These two behaviors were the most well-known behaviors of the poor people at the bottom of the Middle Ages, so they were repeatedly used in theatrical creation. For example, in "The Second Shepherd's Play", Mike stole the sheep of the shepherd, "Three priests" who showed the miracles of Saint Nicholas were stolen by the gangster, and the hero in "Portrait of Saint Nicholas" Portraits are stolen, etc. These theft plots and the funny elements they carry can easily remind us of comedy works of ancient Rome Plautus and Terrence. The decoy behavior can be seen in the drama of Adam in which Satan tempts Eve to eat the fruits of the tree of knowledge of good and evil, the stolen Mike steals the trust of the shepherd, etc. These concealment and deception behaviors were funny in ancient Greece and Rome. The play is also well known to us.

These are full of illustrations that religious dramas in the late Middle Ages continued to break through the limitations of the Bible story in terms of subject matter and content, and became more colorful.

\footnotetext{
4 Yang Huilin. Christianity Background and Cultural Extension [M]. Harbin: Heilongjiang People's Publishing House, 2002, p.249
} 


\section{Changes in performance techniques - the use of comedy techniques and the increase of Harlequins}

As mentioned above, the first half of The Play of the Second Shepherd is very similar to Greek and Roman comic comedies. It uses misunderstanding, exaggeration, satire and puns to create a series of comedic situations, such as Jill Maternity, put a stolen sheep in the cradle as a newborn baby, and when the shepherd found that the baby in the cradle had a sheep nose, he thought the baby was "malformed" and heard Mike said that it was ridiculous. In the play, a lot of puns are also used. For example, Mike swears to the shepherd that if he lies, "this (the child in the cradle) is the first meal I have today," an informed audience can catch a smile.

The increasing number of comedy elements in religious dramas is not only manifested in the application of comedy techniques, but also includes the increase of comedic roles such as harlequins and its various laughter episodes that lead to various gags. Harlequins such as Satan, businessmen, sheep stokers, Noah's wife, artisans, and Herod became more and more harlequinized. In the drama of "Mary's Match", Maria's husband Joseph is a harlequin figure, similar to the kind of cuckold man in the vulgar and funny story that the citizens liked at the time. He is kind and is an elderly man. The bishop obeyed the angel's order to choose a husband for Mary among the unmarried men of the David family. Joseph realized that he had been selected. He was terrified and decided to shirk: "What, should I get married? No! I am old and God helps me, and now it is not good to have a wife and live in fear and fright. The old man is worthy of his young wife. There is no end to it. "After marrying Maria, he went out to work and earn money. When he returned home, he found that Maria was pregnant, so he said," I'm afraid you betrayed me. After I leave you have someone else." His emotions plummeted and he turned to the audience and said loudly, "Old man, listen to me. If you listen to me, you won't marry a young wife anyway. Oops, oops, I've got a reputation! Everyone can despise it! I said, 'Old man in the green hat, your bow has been pulled open with a French head."' And when the angel explained it, Joseph immediately seemed to have good luck, and said to Mary excitedly, "Oh, I The magnanimous wife, I said the wrong thing, and show mercy! All my words are taken back." And kiss Mary's feet. This religious drama looks exactly like a light comedy. This plot is a bit similar to Platos's "Motherin-law". It is also about a woman who is pregnant with her husband on her back, which leads to a series of interesting plots such as concealment and discovery. The seriousness of pagan drama is being weakened and replaced by game-like hilarity. These harlequins are characters extracted from secular life. With the development of medieval European cities and the prosperity of the capitalist economy, secular themes including love dramas, marriage dramas, and crime dramas have gradually penetrated into religious dramas, and become important parts of it. The play of the first survivor in the Middle Ages, Rose Visa, basically belongs to the category of comedy or has many comedic factors.

\section{Secularization of religious music}

Religious music is organized around religious rituals. It includes chanting music, saint music, and funeral music. The System of Music by Poesius (ca. 480-524) fully expresses the essence of Christian music-righteousness, emphasizing the moral influence and educational role of music. Music is mainly regarded as a rational activity that recognizes laws, rules, and principles, rather than emotional expression in emotional life. Music should not focus on auditory pleasure, but it is the harmony of the soul. The church uses music as a means to cultivate the faith of the faith and propagate the doctrines. Church ritual dramas first came from the "songs" or "continuations" derived from the "hallelujah" singing at the end of the mass. The entertainment of music itself is actually reduced and controlled by the church's efforts. However, such control is limited. Soon the music of religious rituals will begin to secularize. On the one hand, is the religious music composers' constantly retouching, on the other hand, is the penetration of secular music into church music.

As mentioned above, religious dramas are derived from the "Derivatives" in the mass ritual. "Derivatives" is a "continuation" of church music. It is music with elaborate lyrics of prose poems, so it is easy to pop. Soon, this monophonic "continuation" developed into polyphonic music. After the 13th century, polyphonic singing such as "Clausula" and scripture songs with fixed songs as the melody rose. The back lyrics have also been added to the scripture songs, and the content of the lyrics has gradually become secular, even including the content of love and amusement. The "Art Nouveau" was born in France, and composers used music as a way of expressing emotions. This entertaining tone was suppressed by the church. After the Reformation, secular tunes have increasingly entered into religious music.

\section{E. The completion of secularization - the formation of urban drama}

By the late Middle Ages, the emergence of moral dramas had shown the beginning of religion. From faith to morality, it was a shift from attention to God to people. ${ }^{5}$ "(Ethical dramas) are often written for court or principals for their students," with the aim of giving religious morals. This type of drama is characterized by

Edited by Liu Jianjun. Foreign Literature [M]. Beijing: Higher Education Press, 2008, p. 20. 
the use of signs and allegorical characters in the play, showing the struggle between good and evil in order to win human souls. Emblem is the use of specific signs or objects to express the concept of pumping, for example, Wang Zhan represents kingship, heart represents love, dove represents peace, and so on. The characters in the allegorical drama begin with anthropomorphic techniques. The so-called anthropomorphism is to use a specific person to represent an abstract nature (such as justice, mercy), institutions (such as the church), or moral types (such as sinners, rich people).

Moral plays are represented by The Fortress of Endurance and Everyone. "Fortress" in the title of the "Fortress" represents the soul. The whole show shows the various temptations and attacks suffered by the human soul, and its final salvation comes from the mercy of God. "Everyone" shows that at the end of life, people realize what they can do to save his soul. "Everyone" finds "friends", "relatives", "wealth" and other colleagues are rejected. "Good deeds" accompany him to the end. Moral drama anthropomorphizes various characteristics of human nature to show the battle between goodness and viciousness. People have retreated from spiritual battles and defended morality within a narrow worldly scope. This was the need for moral control under the increasingly dark, corrupt and chaotic church rule and social order in the late Middle Ages. The church "top-down arrogance and immorality and non-cultivation have rendered the so-called religious beliefs useless, so that the attachment and indulgence of worldly desires has become a universal atmosphere of both the religious and the cultural world." 6 Moral drama can be said to be a transitional form of the transformation of religious drama to secular drama. Later urban drama was born.

After the 13th century, the church's actual control over people became increasingly limited. In the 12th century, religious plays in English and French appeared, in addition to English "folk drama" and French "non-religious drama", that is, "urban drama" and "secular drama", such as the British St. George's drama and Robin Han opera. Ancient Roman and French comedy traditions are inherited in English and French secular dramas. Even in the early days of the Roman Empire, the colors of Farce and Pantomime had penetrated deeply into the form of drama. The farce at the time followed from the Greek comic mime that originated in Sicily. Ethnic dramas have continued to develop, and the expressions of religious dramas have been developed both in music and dance. After the fourteenth and fifteenth centuries, religious dramas were mostly performed in local dialects, rather than Latin. The number of actors in the actor has increased.

Yang Huilin. Christianity Background and Cultural Extension [M]. Harbin: Heilongjiang People's Publishing House, 2002, p.248.
Mime and fool drama can be included in the scope of secular drama, but it is interesting that mimes are often performed on the same stage with serious religious dramas, becoming an interlude of lengthy religious dramas to relieve tension, and fool dramas are born April Fool's Day, it also has a great impact on the development of comedy.

With the development of urban drama, the church's indoor drama is also being staged, but it is more focused on stage technology, and the "flying car" pulled by rope is one of the achievements of this technological development. By the 15th century, professional theater troupes were born, and literati dramas with talented college students also gradually developed.

\section{CONCLUSION}

Religious drama of the Middle Ages flourished for 6 centuries. It laid a different tradition for Renaissance drama than tragic comedy in ancient Greece and Rome, which had not been realized in the past. Shakespeare's historical dramas and tragedies are good at drawing nutrients from religious dramas. For example, King Lear has adaptations of Saint Nicholas and Dowry of Three Daughters, and Henry Foster's Foster Star. The "husband" image is a reference to Mike in "The Second Shepherd Play". The secularization of religious drama is the inevitable development of urban economy and the demand for entertainment of the drama itself. The rise of European national drama hastened the process of this secularization, and finally ushered in the era of Renaissance literati drama.

\section{References}

[1] Yang Huilin. Christianity Background and Cultural Extension [M]. Harbin: Heilongjiang People's Publishing House, 2002.

[2] Liu Jianjun, Chief Editor. Foreign Literature [M]. Beijing: Higher Education Press, 2008.

[3] (British) Simon Trussler. Cambridge Illustrations of British Drama History [M]. Translated by Liu Zhenqian, Li Yi, Kang Jian. Shandong Pictorial Press, 2006.

[4] (US) Brockett (O.G.). Appreciation of World Drama Art History of World Drama [M]. Translated by $\mathrm{Hu}$ Yaoheng. Beijing: China Drama Press, 1987.

[5] William Tydeman. The Theatre in the Middle Ages [M]. Beijing: Cambridge, 1978.

[6] (US) M.L.F. Bellinger. History of Western Dramas [M] Translated by Yin Yanlin. Wentong Bookstore, 1943.

[7] He Qizhen. History of British Drama [M]. Phoenix Publishing Media Group Yilin Press, 2008.

[8] Ju Jiliang. Religion and Secular Choice — Thinking from Medieval European Drama [J] .Art of Drama, 1989 (04).

[9] Du Xiaoyun, Ren Aizhen. Medieval drama that cannot be ignored [J]. Sichuan Theatre, 2007 (6).

[10] Li Peng. The Carnival of European Medieval Drama [J]. Drama Literature, 2006 (6). 